\title{
HIGH COUNTRY GRASSLANDS IN NEW ZEALAND: \\ Their Characteristics and Problems
}

\author{
By L. P. CHAPMAN, Mt. Somers, Canterbury.
}

From the farming point of view the high country of the South Island of New Zealand is generally taken to mean all the high native grassland devoted to the growing of wool and store stock and subject to risk of snów.

This covers some 12 million acres of country with a great variety of topography, climate, and soils, Rainfalls range from $12 \mathrm{in}$. in the arid regions of Otago to over $100 \mathrm{in}$. in the heavy rainfall areas close to the main ranges, and soils and vegetation vary accordingly. The winter is long and the growing season short, a maximum of 6 months in most districts.

\section{Classification}

From the grasslands angle it can perhaps best be classified by the dominant cover. The silver tussock (Poa caespitosa) mostly grows in the lower and warmer country and so is outside the area under consideration. Next we have the fescue tussock (Festuca novae-zelandiae), which is the common tussock of the high country, covering the bulk of the area of occupied land. Then on the higher and colder country snow tussock (Danthonia flavescens, etc.) becomes dominant. With increasing altitude this is succeeded by herb-field and mat-forming grasses, which in turn give way to scree and bare rock. These main classes merge into one another with all the infinite gradations of nature.

\section{Development}

The Past. The suitability of this native country for sheep farming was early realised and the greater part of it was occupied by pioneering spirits within a few years of settlement of the country. It provided natural, healthy pasture for sheep, especially Merinos, without any heavy labour such as the bush clearing of the North Island. The hazards of the early days 


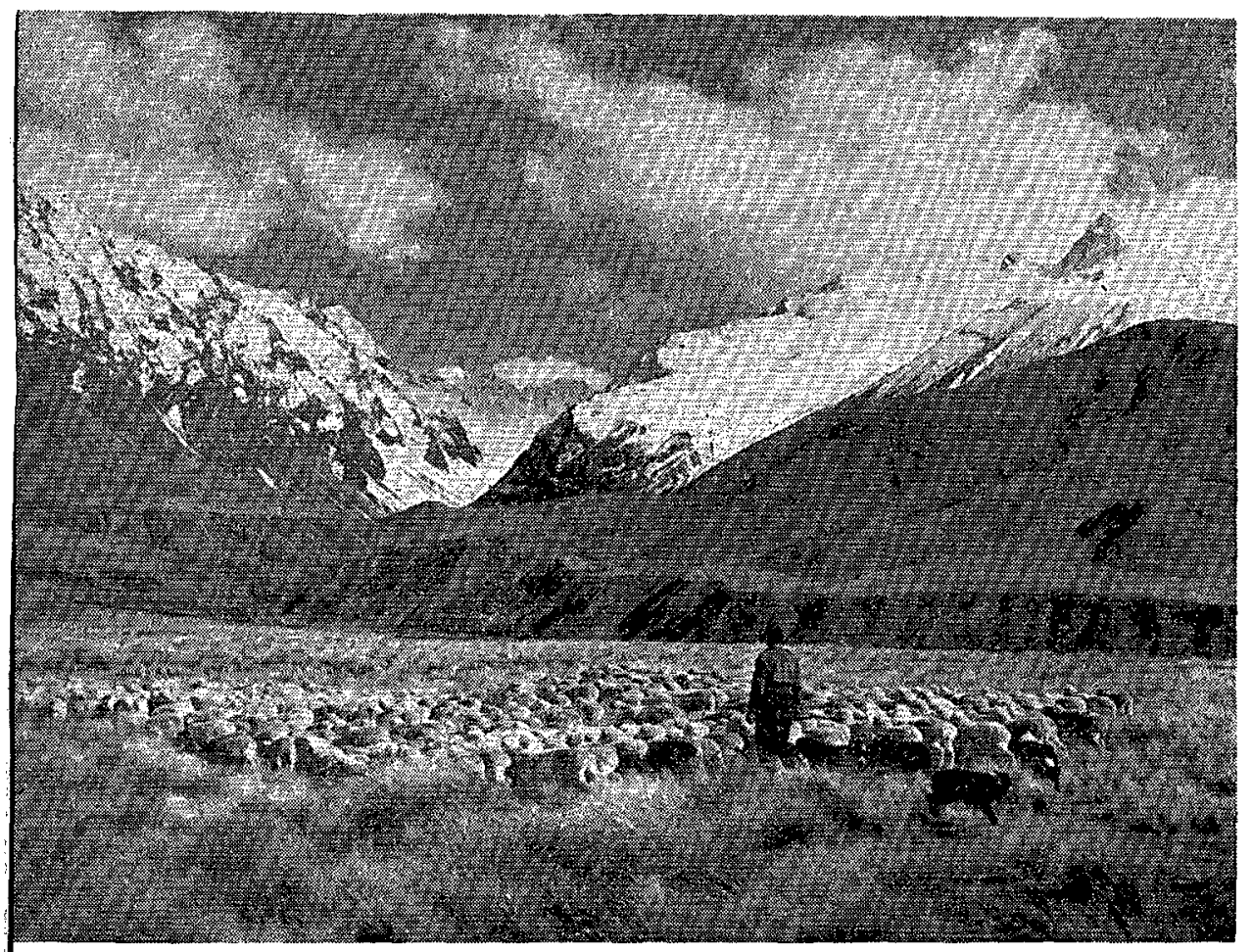

From the farming point of view the high country of the South Island is generally taken to mean all the high native grassland devoted to the growing of wool and store stock and subject to the risk of snow.

were chiefly difficulties of access, of handling stock in rough country, of heavy snowfalls, and of inflammability of the vegetation ; and these difficulties are still the hazards of today.

The early stages of farming this country were largely a matter of trial and error, the only course where no previous experience existed as a guide. Stock numbers were inevitably pushed up to a maximum; and as changes in cover are comparatively slow to show up, there was a lag in the evidence of overgrazing. As a result there was a living on capital of the grazing potential, to the extent that some palatable species, aniseed for example, were eaten out. There was also, of course, an inevitable deterioration of cover in a country hitherto unstocked and so rudely disturbed by man's occupation.

Since the peak numbers of about 60 years ago a gradual reduction of stocking has taken place to numbers which approximate the annual production of feed. 
Other factors, such as a profitable outlet for surplus stock and a shortage of experienced labour to work the country, have contributed to the reduction to present day numbers.

The real achievement of early high country farmers lies in the breeding of stock suited to the conditions, the evolution of a system of management adapted to a mountain environment, and the pitting of men, dogs, and horses against the elements of mountain, river, and storm.

The Present. The present might be termed a period of consolidation. The reduction in stock carried and improved breeding have led to a higher return per sheep, due to a heavier wool clip, a higher lambing percentage, and a reduction in the death rate-all critical factors in high country farming.

The advantages of mechanisation, for long restricted to low country farmers, are now becoming available to the high country farmers, with the advent of aeroplanes, four wheel drive vehicles, crawler tractors,- and snow ploughs.

The Government has contributed to this consolidation in several ways. The placing of rabbit and deer control on a national basis is a policy which has proved amply justified. Administration reforms, such as the regrouping of leases for a better balance of summer and winter country and improved tenure of leases and the development of more satisfactory relationships with the Lands Department as landlord have all contributed to the long-term confidence so necessary for a tenant to make the most of his land. Nor should I omit to mention the assistance in investigation and instruction which is now being given to the back country by the Department of Agriculture, Lincoln College, and other bodies.

No type of farming can be considered realistically without taking into account the question of economics, or, putting it in plain words, does it pay? This must, as in any business, be the over-riding consideration in any long-term policy of farming, and more particularly so when any development involving capital expenditure on leasehold land is contemplated. The higher wool prices of the last few years have lifted high country farming from its previous depressed state. This prosperity has been quickly reflected in improvements to buildings, fences, tracks, etc., to the extent that availability of materials and labour allows. The farmer has also turned his attention to the possibilities of 
improvement to feeding and management practices and to improvement of the country itself. Problems of access, labour, and education remain, but are outside the scope of this paper.

\section{$M$ anagement}

This varies considerably with the individual conditions of each property. However, it is primarily a system of extensive grazing governed by two main factors. These are the difficulty of mustering or handling sheep in the rough terrain and the risk of loss from snowfalls. The general pattern followed is that hoggets are run on' the most accessible and best grassed areas which are free from snow risk, ewes on the next best country, and wethers on the harder and colder country. Cattle are mostly used only to clean up swamps and gullies, and if run on open sheep country they follow after sheep, rather than prepare the way for them, as is usual on better grassed country. In the autumn all sheep are turned out on the summer country, giving a rest to the intensively grazed lower country. The higher country thus acquires a value greater than its natural carrying capacity.

The true measure of a high country farmer's managerial ability is in terms of his success in breeding a sheep adapted to his particular country and his skill and determination in making the greatest use of his summer country in relation to his winter country. I should perhaps explain that this latter is done not by putting sheep through a gate, but by careful shepherding, arduous walking, and the judicious use of natural boundaries.

\section{Intensity of Stock G razing}

Two approaches to the grazing of tussock country may be made. Firstly a low stocking rate and lax grazing may be adopted. This results in selective grazing and the neglect of the less palatable species and probably a corresponding necessity to burn to clean up the country. Advantages are an assured surplus as winter feed and a lessened risk from dry spells. Secondly, a higher stocking. rate, possibly including cattle,. coupled with an attempt to control the summer growth. This involves a greater necessity for winter provision, and a greater vulnerability to droughts, but a higher gross return and lessened burning for control. Which system is the better, either for the cover of the country or from the point of view of net return, "can probably only be answered for the individual property. 
The actual stocking rate arrived at is the result of long experience and observation on the part of the farmer and also latterly by the Lands Department as landlord. The average may vary from one sheep to two acres to as low as one sheep to 10 acres. On a primarily wool producing property the maximum total wool clip from the minimum numbers of sheep over a period of years provides some measure of the suitability of the rate of stocking.

\section{Cover}

Let us now turn to the question of the cover of the high country grass lands. As in all hill country, cover serves both as protection and as feed for stock. It protects the soil and reduces rainfall runoff, and also gives protection to stock, both as shelter from storms and also from the ability of tussock to break up snow and so minimise the affect of a heavy snowfall.

The outstanding feature of these grasslands is the dominance by tussock species of an unpalatable nature while between the tussocks and among the rocks and scree grow the fine grasses and herbs which provide feed for sheep; the whole evolved in the absence of any grazing animal, unless we include the moa. In this respect New Zealand differs from nearly all other countries and this factor alone makes too superficial a comparison with other countries.

Occupation of these grasslands for farming inevitably resulted in a modification of the vegetation. The original dense cover was opened up by the first settlers by burning. Burning is now restricted and is practised mainly for the removal of rank dead growth or as a precautionary measure against devastating accidental fires. Grazing by stock followed, firstly sheep and then the invasion of rabbits, deer, etc. This invasion by wild animals was parallelled by a similar uncontrolled invasion by aggressive pasture species such as browntop (Agrostis tenuis) and Yorkshire fog (Holcus lanatus) accompanied by the inevitable weeds like gorse (Ulex europaeus), St. John's wort (Hypericum perforatum) and sweet briar (Rosa mubiginosa).

The lesson with regard to introducing species, be they animal or vegetation, into the high country should be clear for all to read. The obvious fact is that the moment they are successfully established and have shown their ability to survive you have lost control of their reproduction and spread.

This change in the native vegetation and the accompanying loss of cover and conservation of soil and 
water is the price we have had to pay for occupation, but it must be weighed against the national value of high country production, some three to four million pounds per annum for wool alone at present values.

\section{Improvements}

What are the possibilities of improvement to those high country grasslands, bearing in mind the limits imposed by the economics of farming this type of country.

It may be useful first to define, from the farmer's point of view? what is the ideal pasture. He wants firstly to retain the protective tussock and among it to have a pasture cover which is palatable and nutritious and which will withstand grazing and not grow rank, which has good frost resistance and winter curing properties, and a proper balance of seasonal production. This ideal pasture, it is realised, could only be achieved by taking into account all the factors of climate, soil, vegetation, and the grazing animal.

An elementary principle of improvement which is often overlooked is that to effect improvement to a comparatively stable pasture association we must alter the conditions in some manner. Thus where a high fertility demanding grass such as cocksfoot (Dactylis glomerata) is already present in favoured spots on tussock country, it is of little use to sow it on adjacent harder areas-as is often done by runholders-without first improving the fertility or reducing the intensity of grazing. Avenues for altering the conditions include :

1. Reduction of grazing pressure, either by lowering stock numbers or by the removal of rabbits, with a resulting recovery and reseeding of existing palatable species, both native and introduced. This is the cheapest and commonest method adopted.

2. Greater provision of supplementary feeding in 'winter and early spring either by the growing of forage crops or the feeding of hay and concentrates. The former is well tried, but there appears to be a promising field for investigation of the latter.

3. Raising the fertility by the oversowing of legumes either with or without manure. This has given good results in widely different areas, though few high country soils are sufficiently rich to show a response without manure. Clovers have the ability to establish readily through dense turfs and also on bare soils such as we often find on high country. Clover does not produce nitrogen to the same extent under 
these conditions, but an aspect which is often overlooked is its relatively greater importance as a producer of feed, especially in view of the low protein content of native grasses. Any marked improvement in clover status raises problems of stock management but these should not be insuperable. An unexpected but important result of topdressing tussock country has been the marked improvement in the vigour and health of the fescue tussock itself, and the extent to which stock will clean up roughage that would otherwise be neglected. Greater understanding of soil and plant needs and improvements in manures may be expected in the future. As an illustration of this trend I might mention that field trials are being undertaken on my own property among others with the following objects : reduction in the losses due to fixation of phosphates; increasing the resistance of clovers to frosting; the effectiveness of gypsum in place of superphosphate, In view of the tremendous strides in farming technique and mechanisation of the last 25 years, we can but feel that in another similar period our present day topdressing methods will appear extremely primitive. With the advances in aeroplane performance which can be expected, we niay find, at this stage, to have touched only the fringe of the possibilities. However, improvement of high country by topdressing is expensive and so is limited to special-purpose areas of the better country, such as hogget blocks,. holding paddocks, etc. From there it will grow to more general use if justified.

\section{Plant introduction}

On the other hand introduction of suitable species, native or exotic, which have proved their ability to thrive on the country, unsupported by manuring, offers scope for improving the whole area of the high country, It is in this field that the greatest difficulties occur, and consequently that the greatest challenge is thrown out to the grassland scientist. For instance, research has indicated that the snow tussock is probably on the way out irrespective of man's occupation. The identification and establishment of a plant cover, compatible with grazing, to replace the retreating snow tussock would be of inestimable benefit, There is evidence to "suggest that in some areas the blue tussock might be adaptable to that purpose. The propagation for seed of palatable native species and the introduction of suitable grazing plants from overseas have not made the progress hoped for. But valuable, though sporadic, work under difficult conditions is being done by various interests. 


\section{Conclusion}

I have purposely avoided much mention of the contentious subject of conservation versus occupation for production. Much of that contention is due to lack of knowledge. With a greater fund of factual information as a result of research work done here in New Zealand, on the part of the conservation authorities, and a growing awareness on the part of the farmer of the precarious balance under which the soil and vegetation clothe much of our high country; and with an open mind on the part of both, that contention should be largely resolved.

One thing is certain. That the combined efforts and ability of scientist, extension worker, and farmer will be needed to maintain and improve our national asset-the high country.

\section{DISCUSSION}

Q. Is there not a field for research into the better utilisation of the existing vegetation by evolving a new breed of sheep for the high country?

A. Yes, I would say there is a field there. I run half-breds, but I feel the real opportunity is in developing a type of Corriedale that would suit the country. As far as heavier breeds go, I am doubtful. After seeing Molesworth recently I consider there is quite a bit more scope for cattle in our back country. For the heavier sheep breeds there is a very limited scope. 